\title{
PERSONALITY CHARACTERISTICS OF SERBIAN MALE WHEELCHAIR AND PROFESSIONAL BASKETBALL PLAYERS
}

\author{
Kasum Goran $^{1}$, Ljubiša Lazarević ${ }^{2}$, Saša Jakovljević ${ }^{1}$ Ljubica Bačanac ${ }^{3}$, Fadilj Eminovićc
}

\author{
${ }^{1}$ Faculty of Sport and Physical Education, University of Belgrade, Belgrade, Serbia and Montenegro \\ ${ }^{2}$ College of Sport and Health, Belgrade, Serbia and Montenegro \\ ${ }^{3}$ Republic Institute of Sport, Belgrade, Serbia and Montenegro \\ ${ }^{4}$ Faculty of Special Education and Rehabilitation, University of Belgrade, Belgrade, Serbia and Montenegro
}

Submitted in May, 2011

BACKGROUND: Sport, as social phenomena, may achieve a very positive influence on health and the social state of people with disability who practice it. In sport activities of athletes with disability, team sports may take a very important place.

OBJECTIVE: The aims of this study were - a) to investigate personality characteristics of male professional basketball players and wheelchair basketball players, b) to compare these characteristics of two kinds of athletes.

METHODS: For the purposes of this study, professional basketball players $(\mathrm{N}=29)$ and wheelchair basketball players $(\mathrm{N}=25)$ had completed a Cattell $16 \mathrm{PF}$ questionnaire which estimated personality characteristics. Differences between two groups of participants were calculated by t-test for small samples.

RESULTS: Results demonstrated the existence of differences in the expression of certain forms of behaviour within certain dimensions of personality between these two groups. Wheelchair basketball players had higher scores at factor $\mathrm{M}$ - abstractedness $(\mathrm{t}=-1.889 ; \mathrm{p}=0.046)$, which means that they are more preoccupied by themselves and their inner mental life. Wheelchair basketball players had lower scores, on factors: $\mathrm{C}$ - emotional stability $(\mathrm{t}=2.097 ; \mathrm{p}=0.041)$, $\mathrm{E}$ - dominance $(\mathrm{t}=3.530 ; \mathrm{p}=0.001), \mathrm{F}$ - liveliness $(\mathrm{t}=2.658 ; \mathrm{p}=0.010)$ and $\mathrm{N}$ - privateness $(\mathrm{t}=2.527 ; \mathrm{p}=0.015)$.

CONCLUSIONS: Wheelchair basketball players are, compared with professional basketball players, more emotive; they have a lack of self-esteem, less ready for teamwork and collaboration; they are naive and unpretentious. Considering these results, coaches who are involved in work with wheelchair basketball players have to adjust their methods of trainings, especially those coaches who were working with basketball players without disability. Also, coaches' influence can stimulate eventual changes in some above mentioned characteristics of wheelchair basketball players in more desirable course.

Keywords: Cattell 16PF, self-esteem, emotions, teamwork.

\section{INTRODUCTION}

In the last fifteen years the number of disabled persons has increased in the Balkan region mainly as a result of traumatic events in this area (Organization War Veterans of Serbia, 2012). Especially, there are a certain number of young people who continue to live their lives with some gained physical disability. Therefore, more and more efforts have been made to enhance the quality of their lives. Sport, as social phenomena, may achieve very positive influence on the health and social state of people with disability who practice it (Miyahara et al., 2008; Wells \& Hooker, 1990). There are psycho-social benefits of participating in sports for people with disability (Campbell \& Jones, 1995; Hutzler \& Bar-Eli, 1993). People with disability who participate in sports have been shown to handle pressure and stressful situations better than those who do not exercise. They also experience less depression, confusion, tension and anger
(Campbell \& Jones, 1994; Paulsen, French, \& Sherrill, 1990).

In sport activities of athletes with disability, team sports may take a very important place (Hutzler \& Bar-Eli, 1993; Sporner et al., 2009). Considering the fact that there are more participants who play together, athletes with disability are motivated to communicate and make connections with others. Result of this may improve their general state. Team sports have great tradition and popularity in Serbia, especially basketball (Paunic, 2007). There are also a great number of basketball clubs in Serbia. Basketball is complex and poly-structural activity (Drinkwater, Pyne, \& Mckenna, 2008; McInnes et al., 1995), therefore playing basketball has multiple influences on the basketball player's body and his psycho-social characteristics. One of the most important approaches in practicing basketball is relationship between coaches and players. Coaches have to be very good psychologists (Wooden, 1998). Studies 
of psychological profiles and personality of athletes is present in many sports and in basketball as well (Hoffman, Bar-Eli, \& Tenenbaum, 1999; Maddi \& Hess, 1992; Svoboda, 1993)

The development of psychological skills of athletes with disabilities has not been sufficiently studied (Bawden, 2006; Hanrahan, 1998). Although there are many similarities among athletes with and without disabilities, sport psychologists would benefit from an awareness of information unique to athletes with disabilities (Asken, 1991). Martin (2008) investigated performance, training, and resiliency, and thought control self-efficacy, positive and negative affect with wheelchair basketball athletes and found that basketball players who were efficacious in their ability to overcome training barriers were also confident in their basketball skills and efficacious in their ability to overcome ruminating distressing thoughts while simultaneously cultivating positive thoughts. Skordilis, Gavriilidis, and Asonitou (2003) found significant differences among male professional, amateur and wheelchair basketball athletes in sport achievement orientation and win orientation. It was the factor, through discriminated function analysis, that significantly divided the athletes into three groups. Professional players achieved the highest win score, followed by amateurs and wheelchairs groups.

Wheelchair basketball has been developed lately in Serbia. There is more interest from basketball coaches, who were training only with basketball players without disability, in training wheelchair basketball players. To train more effectively wheelchair basketball players they have to study wheelchair basketball players' psychological characteristics.

The aims of this study were: a) to investigate personality characteristics of male professional basketball players and wheelchair basketball players, b) to compare these characteristics of male professional basketball players and wheelchair basketball players (the First National League).

\section{METHODS}

\section{Participants}

Participants were 25 wheelchair basketball players, from four top wheelchair basketball clubs (group 1) and 29 male professional basketball players, from four top basketball clubs (group 2). They had similar level of basketball proficiency according to their category (the First National League). The mean age for wheelchair players was 33.5 years $(S D=8.66)$, and the average playing experience was 5.60 years $(\mathrm{SD}=1.98)$. According to their classification seven players were classified as 1 , three players as 1.5 , four as 2 ; four as 3 , two as 3.5 , three as 4 , and two as 4.5 . The mean age for professional basketball players was 26.34 years $(S D=4.48)$, and the average playing experience, in professional basketball, was 8.65 years $(S D=4.27)$.

Twenty wheelchair players had secondary education (high school), one of them is a student and four of them finished university. Twenty of professional players had secondary education (high school), and others (9) were students of a few different universities. All players were healthy.

\section{Instruments and procedure}

For the purposes of this study, wheelchair basketball players and professional basketball players and were asked to complete Cattell 16PF questionnaire (5th ed.), based on the Raymond Cattell's theory of personality. This is standardized questionnaire with high reliability, test/re-test reliabilities are average 0.80 , ranging from 0.69 to 0.87 (Boyle, Matthews, \& Saklofske, 2008). Also, 2 week test/re-test estimates ranged from 0.84 to 0.91 with a mean of 0.87 (Cattell \& Schverger, 2003). The primary factors that the Cattell 16PF test measure are bipolar dimensions of personality - A - warmth (reserved vs. warm); B -reasoning (concrete vs. abstract); C - emotional stability (reactive, instability vs. emotional stable, high ego strength); E - dominance (deferential, submissiveness vs. dominant); F - liveliness (serious, sober vs. lively); G - rule-consciousness (disregards rules vs. rule conscientious, responsibility); $\mathrm{H}$ - social boldness (threat sensitive, shy vs. socially bold, uninhibited); I - sensitivity (tough-minded, utilitarian vs. tender-minded, sensitive); L - vigilance (trusting vs. vigilant, suspicious); M - abstractedness (practical, grounded vs. abstracted, imaginative); $\mathrm{N}$ - privateness (forthright, spontaneous vs. polished, socially aware); $\mathrm{O}$ - apprehension (self-assured vs. apprehensive, anxious); Q1 - openness to change (conservative vs. radicalism, liberal); Q2 - self-reliance (group dependent, “joiner” vs. self-reliant, self-sufficient); Q3 - perfectionism (low self-sentiment, uncontrolled vs. high strength of self-sentiment, controlled); Q4 - tension (relaxed, unfrustrated vs. tense, frustrated).

The protocol used in the present study received institutional approval and informed consent was obtained from each participant. Participants were recruited by contacting their coaches. Coaches were instructed to tell their players that participation was voluntary and that all the information reported in their questionnaire was confidential. Participants completed the questionnaire individually, before practice in the evening in a quiet room. The authors of the project introduced the questionnaire to participants.

\section{Data analysis}

Standard descriptive statistics were calculated mean (M), standard deviation (SD), minimal (Min.) 
TABLE 1

Means and standard deviations of 16 personal factors for both groups

\begin{tabular}{|l|c|c|c|c|}
\hline \multirow{2}{*}{ Variable } & \multicolumn{2}{|c|}{ Wheelchair basketball players } & \multicolumn{2}{|c|}{ Professional basketball players } \\
\cline { 2 - 5 } & Mean & Std. deviation & Mean & Std. deviation \\
\hline A - warmth & 10.96 & 2.99 & 12.00 & 2.67 \\
\hline B - reasoning & 7.36 & 2.22 & 8.38 & 1.92 \\
\hline C - emotional stability & 14.96 & 2.85 & 16.38 & 2.11 \\
\hline E - dominance & 12.16 & 3.51 & 15.20 & 2.83 \\
\hline F - liveliness & 13.93 & 3.13 & 16.48 & 3.84 \\
\hline G - rule consciousness & 14.29 & 2.67 & 14.89 & 2.73 \\
\hline H - social boldness & 14.60 & 4.06 & 15.48 & 5.047 \\
\hline I - sensitivity & 6.40 & 2.29 & 7.31 & 2.58 \\
\hline L - vigilance & 10.32 & 3.04 & 10.96 & 2.48 \\
\hline M - abstractedness & 12.56 & 3.32 & 11.00 & 2.75 \\
\hline N - privateness & 9.00 & 2.31 & 10.55 & 2.20 \\
\hline O - apprehension & 9.48 & 3.24 & 9.69 & 2.99 \\
\hline Q1 - openness to change & 9.60 & 2.16 & 9.55 & 2.83 \\
\hline Q2 - self-reliance & 10.20 & 2.96 & 9.82 & 2.98 \\
\hline Q3 - perfectionism & 12.12 & 2.49 & 13.03 & 2.47 \\
\hline Q4 - tension & 11.24 & 3.64 & & 3.87 \\
\hline
\end{tabular}

TABLE 2

Results of t-test between wheelchair basketball players and professional basketball players

\begin{tabular}{|l|c|c|c|c|}
\hline Variable & $\mathbf{t}$ & Sig. & Mean difference & Effect size r \\
\hline A - warmth & 1.349 & 0.183 & 1.040 & 0.18 \\
\hline B - reasoning & 1.813 & 0.076 & 1.019 & 0.22 \\
\hline C - emotional stability & $\mathbf{2 . 0 9 7}$ & $\mathbf{0 . 0 4 1}$ & $\mathbf{1 . 4 1 9}$ & $\mathbf{0 . 2 8}$ \\
\hline E - dominance & $\mathbf{3 . 5 3 0}$ & $\mathbf{0 . 0 0 1}$ & $\mathbf{3 . 0 4 6}$ & $\mathbf{0 . 4 4}$ \\
\hline F - liveliness & $\mathbf{2 . 6 5 8}$ & $\mathbf{0 . 0 1 0}$ & $\mathbf{2 . 5 6 2}$ & $\mathbf{0 . 3 5}$ \\
\hline G - rule consciousness & 0.836 & 0.407 & 0.616 & 0.12 \\
\hline H - social boldness & 0.700 & 0.487 & 0.882 & 0.09 \\
\hline I - sensitivity & 1.361 & 0.179 & 0.910 & 0.18 \\
\hline L - vigilance & 0.859 & 0.394 & 0.645 & 0.12 \\
\hline M - abstractedness & $\mathbf{- 1 . 8 8 9}$ & $\mathbf{0 . 0 4 6}$ & $\mathbf{- 1 . 5 6 0}$ & $\mathbf{0 . 2 5}$ \\
\hline N - privateness & $\mathbf{2 . 5 2 7}$ & $\mathbf{0 . 0 1 5}$ & $\mathbf{1 . 5 5 1}$ & $\mathbf{0 . 3 3}$ \\
\hline O - apprehension & 0.247 & 0.806 & 0.209 & 0.03 \\
\hline Q1 - openness to change & -0.069 & 0.945 & -0.048 & 0.00 \\
\hline Q2 - self-reliance & -0.460 & 0.648 & -0.372 & 0.06 \\
\hline Q3 - perfectionism & 1.352 & 0.182 & 0.914 & 0.18 \\
\hline Q4 - tension & 0.303 & 0.763 & 0.311 & 0.04 \\
\hline
\end{tabular}

and maximal (Max.) values. Significance of differences between two groups was calculated with independent samples t-test for small samples $(\mathrm{p}=0.05)$ and also, effect size coefficient $(r)$ was calculated. Data processing was done in statistical program SPSS16.

\section{RESULTS}

Cattell 16PF questionnaire descriptive parameters results of professional basketball players and wheelchair basketball players are shown in TABLE 1 . And then 
in TABLE 2 we are able to see that presented results show that wheelchair basketball player personality is significantly different of professional basketball players on traits: C - emotional stability, E - dominance, F liveliness, $\mathrm{M}$ - abstractedness and $\mathrm{N}$ - privateness.

Professional basketball players gain higher average score on factor C - emotional stability (16.38) than wheelchair basketball players whose score on that factor is 14.96. Statistically that difference is significant, on level $(\mathrm{p}=0.041)$, and between small/medium effect size coefficient $(r=0.28)$. On the scale $\mathrm{E}$ - dominance we found significant difference $(\mathrm{p}=0.001)$ between two groups with the average score of 15.20 for professional basketball players and 12.16 for wheelchair basketball players, and with medium effect size coefficient $(r=0.44)$. On the scale $\mathrm{F}$ - liveliness professional basketball players gain a higher average score and difference in this scale is on level $\mathrm{p}=0.010$, with almost medium effect size coefficient $(r=0.35)$. Wheelchair basketball players achieve better average result on the scale $\mathrm{M}$ - abstractedness (12.56) than professional basketball players (12.56), the difference is significant on the level $\mathrm{p}=0.046$, but with small effect size coefficient $(r=0.25)$. Also on the scale $\mathrm{N}$ - privateness we noticed a statistically important difference on level $\mathrm{p}=0.015$ (with almost medium effect size coefficient $r=0.35$ ). Professional basketball players gained distinctively higher results on this scale (10.61) than wheelchair basketball players (9.00).

\section{DISCUSSION}

In the case of professional basketball players, mean values of particular variables are almost equal when compared to the results of top Serbian athletes (Bačanac, 2001). Results of Cattell questionnaire showed partial differences in personality between wheelchair basketball players and professional basketball players. These differences were notable in the expression of certain forms of behavioral patterns within certain dimensions of personality. According to values of effect size coefficients there were mainly medium strength differences between certain personality dimensions.

Wheelchair basketball players were more emotional and had tendencies towards higher impulsiveness (scale C). They exhibited less emotional stability and distress tendency, intolerance on frustration and higher impulsiveness (Campbell \& Jones, 1997; Campbell \& Jones, 2002). Professional basketball players performed higher emotional stability, maturity, persistence, reality toward problems. Wheelchair basketball players were secluded, more submissive, lack of self-esteem, dependence, and had certain elements of obedience and correctness (scale E). On this scale professional basketball players exhibited a stronger need for competitive domination, they are more independent, aggressive, and have more self-esteem than wheelchair basketball players. Professional players showed more readiness for cooperation, they are more energetic, carefree and impulsively lively than wheelchair basketball players less ready for teamwork and collaboration (scale F). Furthermore, results indicated that wheelchair basketball players were preoccupied with themselves and with their inner mental life (scale M). Professional basketball players are more practical, realistic, conventional and officious while wheelchair basketball players are more subjective, non-conventional, and imaginative with insufficient appreciation of logic and practical issues. Wheelchair basketball players exhibited openness, spontaneousness, and highly emotional response and had tendencies for contact (scale N). Professional basketball players' behavior has a more analytical approach to situations, tendency to be distanct, they are more assertive still orientated to calculate in particular situations, and therefore calm. Wheelchair basketball players are more spontaneous, sharp, disposed to contacts, more natural. Results on factor $\mathrm{N}$ can in some way confuse and reveal unexpected assumptions considering their state. Therefore it is advisable to conduct additional research, which considers all other scales within personality profile results or find the reason for behavioral differences between these two groups.

Professional basketball is sport activity with numerous "conflict" situations and intrusive sounds. That is why professional basketball requires good psychological and above all emotional stability (Maddi \& Hess, 1992; Svoboda, 1993). Apart from that in the field of professional basketball, strong, tough competition and competitive dominations are expected and highlighted. High levels of self esteem, independence, tendency to be calculative and calm are characteristics for professional basketball player's personality. Considering the fact that achieved result is only one criteria of success, which depends on quality, mutual collaboration among players and collaboration between players and the trainers, it is expected that professional basketball players have highlighted readiness for teamwork or collaboration. These are in concordance with findings that sport achievement orientation and win orientation are the factor which significantly divided professional, amateur and wheelchair basketball athletes into three groups (Skordilis et al., 2003; Skordilis, Koutsouki, Asonitou, Evans, \& Jensen, 2002).

On the other hand, wheelchair basketball players have less emotional stability, tendency to get upset, lack of self-esteem and they are more secluded, self-critical and dependable. They show highlighted depression, shyness and they are more preoccupied to subjective nonconventional events. Moreover, they are not that practical, but they are more natural, spontaneous and easy in making contacts. Wheelchair basketball players, who 
were target group of this study, participate in the competitions that don't have an expressed result component. During competitions they are more concerned with their inner satisfaction or in other words the amount of effort and commitment exhibited in games. Pensgaard, Roberts, and Ursin (1999) found similar results at Norwegian Paralympic and Olympic athletes. There are few clubs with these kinds of players, so most people who want to participate in this sport are welcomed. In fact, there is no financial stimulation (in contrast with professional basketball) or highlighted competitive tension. These facts provide wheelchair basketball players more comfortable approach to the responsibilities, as well as more casual behavior opposite to professional basketball players.

Also, we should consider factors where differences between means are more than 1 - warmth (A) and reasoning (B) in these groups, in spite that differences are not statistically significant. Wheelchair players are less warm, outgoing and kind than professional players, and exhibit lower developed ability of abstract thinking, understanding of ideas, speed of learning and problem solving. These findings may have an important practical significance.

\section{CONCLUSION}

Results demonstrated the existence of statistically significant differences in the expression of certain forms of behaviour within certain dimensions of personality between male wheelchair basketball players and professional basketball players. Values of effect size coefficients show mainly medium strength of an apparent relationship between certain personality dimensions. Wheelchair basketball players are, compared with professional basketball players, more emotive; they lack of self-esteem, less ready for teamwork and collaboration; they are naive and unpretentious. Also, there are relatively great differences (more than 1 ) between means on scales warmth (A) and reasoning (B) in these groups, may be very important for coaches, despite the fact that differences are not statistically significant.

Professional basketball players mean values of particular variables are almost equal when compared to the results of top Serbian athletes (Bačanac, 2001).

Considering these results, coaches who are involved in work with wheelchair basketball players have to adjust their methods of trainings, especially those coaches who were working with basketball players without disability. This is related particularly to coaches behavior within the set up for optimum requests to the players, or in other words sort of "pressure" he or she will apply on the players which would motivate players to make every effort and accomplish requests at training and on game day. On the other hand, coaches ' influence can stimu- late eventual changes in some of the above mentioned characteristics of wheelchair basketball players in more desirable course.

\section{ACKNOWLEDGEMENT}

The work was carried out under the project "Effects of applied physical activity on loco-motor, metabolic, psycho-social and educational status of the Serbian population", no. III47015, which is part of subproject "Effects of applied physical activity on loco-motor, metabolic, psycho-social and educational status of the Serbian elite athletes". The Project has been funded by the Ministry of Science and Technology of Republic of Serbia - the cycle of scientific projects 2011-2014.

\section{REFERENCES}

Asken, M. J. (1991). The challenge of the physically challenged: Delivering sport psychology services to physically disabled athletes. The Sport Psychologist, 5(4), 370-381.

Bačanac, L. (2001). The psychological profile of Yugoslav boxers. Facta Universitatis Series Physical Education and Sport, 1, 13-24.

Bawden, M. (2006). Providing sport psychology for athletes with disabilities. In D. Joaquin (Ed.), The sport psychologist's handbook: A guide for sport-specific performance enhancement (pp. 665-686). Chichester: John Wiley \& Sons.

Boyle, J. G., Matthews, G., \& Saklofske, H. D. (2008). The SAGR handbook of personality theory and assessment (Vol. 2): Personality measurement and testing. London: SAGE Publication Ltd.

Campbell, E., \& Jones, G. (1994). Psychological wellbeing in wheelchair sport participants and nonparticipants. Adapted Physical Activity Quarterly, 11, 404-415.

Campbell, E., \& Jones, G. (1995). Psychological wellbeing and wheelchair users. Journal of Sport \& Exercise Psychology, 17(2), 220-220.

Campbell, E., \& Jones, G. (1997). Precompetition anxiety and self-confidence in wheelchair sport participants. Adapted Physical Activity Quarterly, 14, 95-107.

Campbell, E., \& Jones, G. (2002). Cognitive appraisal of sources of stress experienced by elite male wheelchair basketball players. Adapted Physical Activity Quarterly, 19, 100-108.

Cattell, H. E. P., \& Schverger, J. M. (2003). Essentials of 16PF assessment. Hoboken: John Wiley \& Sons.

Drinkwater, E. J., Pyne, D. B., \& Mckenna, M. J. (2008). Design and interpretation of anthropometric and fitness testing of basketball players. Sports Medicine, $38(7), 565-578$. 
Hanrahan, S. J. (1998). Practical considerations for working with athletes with disabilities. The Sport Psychologist, 12(3), 346-357.

Hoffman, J. R., Bar-Eli, M., \& Tenenbaum, G. (1999). An examination of mood changes and performance in a professional basketball team. Journal of Sports Medicine and Physical Fitness, 39(1), 74-79.

Hutzler, Y., \& Bar-Eli, M. (1993). Psychological benefits of sports for disabled people: A review. Scandinavian Journal of Medicine \& Science in Sports, 3(4), 217-228.

Maddi, S. R., \& Hess, M. J. (1992). Personality hardiness and success in basketball. International Journal of Sport Psychology, 23(4), 360-368.

Martin, J. J. (2008). Multidimensional self-efficancy and affect in wheelchair baskteball players. Adapted Physical Activity Quarterly, 25, 275-288.

McInnes, S. E., Carlson, J. S., Jones, C. J., \& McKenna, M. J. (1995). The physiological load imposed on basketball players during competition. Journal of Sports Science, 13, 387-397.

Miyahara, K., Wang, D. H., Mori, K., Takahashi, K., Miyatake, N., Wang, B. L., Takigawa, T., Takaki, J., \& Ogino, K. (2008). Effect of sports activity on bone mineral density in wheelchair athletes. Journal of Bone \& Mineral Metabolism, 26(1), 101-106.

Organization War Veterans of Serbia. (2012). Invalidity [on-line]. Retrieved 2. 2. 2012 from the World Wide Web: http://www.veterani.org.rs

Paulsen, P., French, R., \& Sherrill, C. (1990). Comparison of wheelchair athletes and nonathletes on selected mood states. Perceptual and Motor Skills, 71, 1160-1162.

Paunic, S. (2007). Geneza i razvoj kosarke [Genesis and development of basketball]. Beograd: Akademija.

Pensgaard, A. M., Roberts, G. C., \& Ursin, H. (1999). Motivational factors and coping strategies of Norwegian Paralympic and Olympic winter sport athletes. Adapted Physical Activity Quarterly, 16, 238-250.

Skordilis, E. K, Gavriilidis, A., Charitou, S., \& Asonitou, K. (2003). Comparison of sport achievement orientation of male professional, amateur, and wheelchair basketball athletes. Perceptual and Motor Skills, 97(2), 483-490.

Skordilis, E. K., Koutsouki, D., Asonitou, K., Evans, E., \& Jensen, B. (2002). Comparison of sport achievement orientation between wheelchair and able-bodied basketball. Perceptual and Motor Skills, 94(1), 214-218.

Sporner, M. L., Fitzgerald, S. G., Dicianno, B. E., Collins, D., Teodorski, E., Pasquina, P. F., \& Cooper, R. A. (2009). Psychosocial impact of participation in the National Veterans Wheelchair Games and Winter Sports Clinic. Disability \& Rehabilitation, 31, 410-418.
Svoboda, B. (1993). Analysis of personality studies of top basketball players. Acta Universitatis Carolinae: Kinanthropologica, 29(1), 57-61.

Wells, C. L., \& Hooker, S. P. (1990). The spinal injured athlete. Adapted Physical Activity Quarterly, 7, 265-285.

Wooden, J. R. (1998). Practical modern basketball (3rd ed.). San Francisco: Benjamin Cummings.

\section{CHARAKTERISTIKA OSOBNOSTI SRBSKÝCH BASKETBALISTU゚-VOZÍČKÁŘŮ A PROFESIONÁLNÍCH BASKETBALISTŮ}

(Souhrn anglického textu)

VÝCHODISKA: Sport jak sociální fenomén může mít velmi pozitivní vliv na zdraví a sociální situaci osob s postižením, které jej provozují. Velmi důležité místo mezi aktivitami postižených sportovců mohou zaujímat kolektivní sporty.

CíL: Studie měla tyto cíle - a) prošetřit charakteristiku osobnosti profesionálních basketbalistů a basketbalistů-vozíčkářů; b) porovnat tyto charakteristiky dvou druhů sportovců.

METODY: Pro účely této studie profesionální basketbalisté $(\mathrm{N}=29)$ a basketbalisté-vozíčkáři $(\mathrm{N}=25)$ vyplnili dotazník Cattell 16PF, v němž jsou ohodnoceny charakteristiky osobnosti. Rozdíly mezi oběma skupinami účastníků byly spočteny pomocí t-testu pro malé vzorky.

VÝSLEDKY: Výsledky prokázaly výskyt rozdílů mezi oběma skupinami ve vyjádření určitých forem chování v rámci určitých dimenzí osobnosti. Basketbalistévozíčkáři zaznamenali vyšší skóre $\mathrm{u}$ faktoru $\mathrm{M}$ - roztržitost $(\mathrm{t}=-1,889 ; \mathrm{p}=0,046)$, což znamená, že se více zabývají sami sebou a svým vnitřním duševním stavem. Basketbalisté-vozíčkáři zaznamenali nižší skóre u faktorů $\mathrm{C}$ - emocionální stabilita $(\mathrm{t}=2,097 ; \mathrm{p}=0,041), \mathrm{E}$ dominance $(\mathrm{t}=3,530 ; \mathrm{p}=0,001), \mathrm{F}$ - živost $(\mathrm{t}=2,658$; $\mathrm{p}=0,010)$ a $\mathrm{N}$ - odloučenost $(\mathrm{t}=2,527 ; \mathrm{p}=0,015)$.

ZÁVĚRY: Basketbalisté-vozíčkáři jsou ve srovnání s profesionálními basketbalisty více emocionální; mají nižší sebeúctu, jsou méně připravení na týmovou práci a spolupráci; jsou naivní a skromní. Na základě těchto výsledků musejí trenéři, kteří pracují s basketbalisty-vozíčkáři, přizpůsobit své tréninkové metody, zejména ti trenéři, kteří dříve pracovali s hráči bez postižení. Vliv trenérů může také podnítit eventuální změny v některých $\mathrm{z}$ výše uvedených charakteristik basketbalistů-vozíčkářů žádoucím směrem.

Klícová slova: Cattell 16PF, sebeúcta, emoce, týmová práce. 


\section{prof. Goran Kasum, Ph.D.}

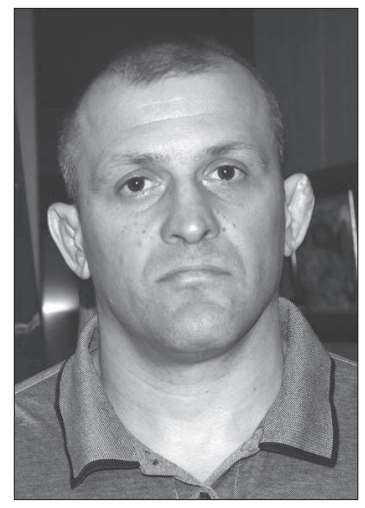

University of Belgrade

Faculty of Sport and Physical Education

Blagoja Parovića 156

11000 Belgrade

Serbia

\section{Education and previous work experience}

Associate professor in a subjects - martial arts, adapted sports.

President on Wrestling Federation of Belgrade.

\section{First-line publications}

Kasum, G., Ćirković, Z., \& Jovanović, S. (2012). Rvanje [Wrestling]. Belgrade: University of Belgrade, Faculty of Sport and Physical Education.

Kasum, G., \& Bačanac, Lj. (2007). Interconnection between some psychological characteristics of elite wrestlers and their main scoring techniques. Physical Culture, 61(1-2), 13-24.

Kasum, G., \& Radović, M. (2009). Connection of some morphological characteristics of best wrestlers and their main scoring techniques. In 10th Sport kinetics Conference Belgrade 2007 "New ideas in fundamentals of Human Movement: Current issues and perspective" (pp. 287-295). Belgrade: IASK.

Kasum, G., \& Ćirković, Z. (2009). Martial arts in the curriculum in school physical education. In International Scientific Conference ,Theoretical, methodology and methodical aspects of physical education “ (pp. 313-319). Belgrade: University of Belgrade, Faculty of Sports and Physical Education.

Kasum, G., Gligorov, S., \& Nastasić-Stošković, T. (2011). Combat sports for persons with disabilities. Physical Culture, 65(1), 60-69.

Kasum, G., Bačanac, L., \& Jakovljević, S. (2011). Characteristics of personality profiles of elite wrestlers and baskteball players. Acta Kinesiologica, 5(1), 16-20.

Kasum, G., Lazarević, L., Jakovljević, S., \& Bačanac, L. (2011). Personality of male wheelchair basketball players and non-athletes persons with disability. Facta Universitatis, 9(4), 407-415. 